\title{
Online Learning Media on Biology Conservation: Rawa Danau Nature Reserve Website
}

\author{
https://doi.org/10.3991/ijim.v15i08.21567 \\ Suroso Mukti Leksono $\left.{ }^{(}\right)$, Pipit Marianingsih, \\ Eprian Nur Ilman, Nani Maryani \\ Universitas Sultan Ageng Tirtayasa, Kota Serang, Indonesia \\ sumule56@untirta.ac.id
}

\begin{abstract}
The use of digital technology in education is an important topic for developing increased access to education through access to various digital platforms and through the provision website as online learning media. Learning websites can load text information, images, videos, animation, sound, or a combination of these and can be widely accessed. This research develops an interactive website for Rawa Danau Nature Reserve in Banten, Indonesia, to support conservation education through online learning. A 3D research and development methodology were used, including three stages: define, design, and develop. The define stage involved data collection through requirements analysis, curriculum analysis for biology conservation, and content analysis. A website presenting Rawa Danau Nature Reserve was developed in the design stage. In the development stage, the website was assessed by an expert in terms of both, its content and learning media. The expert found that the website was feasible for use as online learning media for biology conservation education, in terms of both, content material and learning media.
\end{abstract}

Keywords - Conservation education, Rawa Danau, nature reserve, online learning, website

\section{Introduction}

In the beginning of 2020, the World Health Organization (WHO) announced that COVID-19 had reached global pandemic status [1]. This impacted daily social activity, from the mandatory used of masking and physical distancing to the extreme lockdown, mandating no social activity in the city. The Indonesian government imposed the closure of public places such as schools, public offices, markets, and mosques to limit the spread of the disease. Fortunately, the advancement of technology has provided a solution for maintaining social daily activities, such as working and studying from home. We are able to communicate and interact using a range of platforms from our computers and cellular phones through internet connections.

The Indonesian Ministry of Education has issued a new curriculum adapted to the new normal of the pandemic called "Merdeka Belajar" [2]. The new curriculum incorporates online learning platforms such as Rumah Belajar, Google Classroom, 
Zoom, Ruang Guru, Quipper, Zenius, and others. These platforms are being developed for improved usage [1]. In using these platforms, teachers need to provide learning sources and use appropriate media in their online classrooms. Online learning is the most effective means of instruction in the current pandemic period [1-5]. The availability of additional online-based learning media is needed for online classrooms.

The use of online learning sources has many advantages over traditional approaches that are usually used in the class room, such as the flexibility and accessibility of these resources in different time and places [6,7]. They can also be accessed from different devices, such as the students' personal computers (PCs), electronic notebook, and cell phones. There are six components that contribute to creating successful online learning, namely internet connectivity, interactive content (allowing students to learn at their own pace in groups or individually), a usable classroom management system (availability of facilities and a classroom atmosphere that supports learning), mobility, collaboration, and learning management [8]. The use of online learning sources could increase students' scientific thinking [9]. One type of such online learning sources is an open website.

A learning system developed using websites and mobile learning can be used to help users search for information directly from their smart-devices anytime and anywhere $[10,11]$. Website-based learning sources can respond to the needs of learning processes, such as (1) management and content learning, (2) constructivist learning, (3) learning processes presented with searchable content material and discussion fora with active comments, (4) interactive content that can be modified depending on learning needs, and (5) accessible content that can be downloaded and shared via URL-type links [12]. The content quality, design quality, usability, functionality, and reliability of a website are important aspects of its use [13,14].

Websites can be developed and modified as needed, such that they can be used for learning in accordance with student's competencies and requirements for teaching and learning [15]. Thus, a website can have optimal impact if it is designed properly [16]. In the Indonesian education curriculum, students study conservation education, as Indonesia is among the foremost countries in the world in terms of biodiversity, and it was determined to provide the population with an improved ability to manage biodiversity resources to maintain sustainability as well as improved awareness of the need to do so. Rawa Danau Nature Reserve (in Indonesian, Cagar Alam Rawa Danau) is a conservations area in Banten Province, Indonesia. It is located in between the West Tukung Gede Barat and East Tukung Gede mountains. Rawa Danau is the only mountainous swamp on Java, and it features a rich biodiversity of animals and plants. It hosts 64 bird species, 10 amphibian species, 19 fish species, and 27 dragonfly species. It is also the habitat of many endemic species of plants and swamp flora, including 30 species of swamp plants, 84 species of medicinal plants, and 10 species of bamboo [17]. Many plants and animal species have not been recorded or well identified in this area, so additional study of the biodiversity of Rawa Danau is necessary.

A significant problem for Rawa Danau Nature Reserve in relation to biodiversity is the effects of human activities in the location, which can disrupt the habitat of many species. Due to the poor economy and the low levels of awareness and knowledge of nature conservation also play an important role. Environmental awareness and nature 
conservation can be expected to encourage people to act in an environmentally friendly manner and avoid damaging the ecosystems around them. Environmental awareness can help create harmony between people and their environment and enable nature to be preserved and sustained [18].

Knowledge and awareness of the environment are not possible without proper education and understanding of possible impacts. One way to increase environmental awareness is through conservation education, which can be taught at any level. Education in biological conservation is a learning process that teaches how to use nature wisely and responsibly for present and future generations [19]. The goals of conservation education have five aspects: knowledge, awareness, attitude, skills, and participation.

Education on biological conservation can be implemented through appropriate learning sources. During the current pandemic, it is important to choose learning sources that follow regulation and safety protocols. Therefore, we developed a website to describe the biodiversity of Rawa Danau Nature Reserve to support biology conservation education through online learning. This website provides information for students and the public on the biodiversity in Rawa Danau Nature Reserve and the importance of nature conservation as well, which is expected to improve environmental awareness.

\section{Methodology}

A 3D model methodology was used that includes three stages: define, design, and develop. The define stage involved data collection through requirements analysis, curriculum analysis for biology conservation, and content analysis. The website for biology conservation was developed in the design stage. The development stage was the creation of the Rawa Danau Nature Reserve to support conservation education website-Pendidikan Konservasi Cagar Alam Rawa Danau. In this stage we used a multimedia development life cycle approach that consisted of six phases: concept, design, material collecting, assembly, testing, and distribution. These phases were not considered necessary for construction in order. However, the concept phase needed to be drafted first, before the other phases [20]. The following describe the details of each phase in the development of the website.

\subsection{Concept}

In this phase, the requirement analysis and curriculum analyses were conducted. The requirement analyses were performed by interviewing experts and environmental specialists, as well as visitors and people living in the surrounding of Rawa Danau Nature Reserve. The questions and indicators investigated during the interview are shown in Table 1. 
Table 1. Aspects of requirement analyses for Rawa Danau Nature Reserve website

\begin{tabular}{|c|l|l|}
\hline No. & \multicolumn{1}{|c|}{ Aspect } & \multicolumn{1}{c|}{ Indicator } \\
\hline 1 & Knowledge & $\begin{array}{l}\text { Knowing the importance of biology conservation and information on Rawa } \\
\text { Danau Nature Reserve }\end{array}$ \\
\hline 2 & Utility & $\begin{array}{l}\text { Knowing the use of Rawa Danau Nature Reserve and its surrounding areas for } \\
\text { life resources such as food, wood, and resources }\end{array}$ \\
\hline 3 & Threat & $\begin{array}{l}\text { Knowing the possible threats to Rawa Danau Nature Reserve and its surrounding } \\
\text { areas }\end{array}$ \\
\hline 4 & Conservation & Attempts for conservation of Rawa Danau Nature Reserve \\
\hline
\end{tabular}

Curriculum analysis was conducted through drafting the learning outcomes (kompetensi dasar) for biological conservation education. Conservation involves five aspects: knowledge, awareness, attitude, skill, and participation. The learning outcomes were derived for certain indicators to describe the impact of the website on broader audiences or users.

\subsection{Design}

In this stage, the content of the website was created including its design, layout, web navigation, and storyboard (Fig. 1). It was considered that a more attractive website would be easier for the user or visitor to Rawa Danau Nature Reserve to understand its purpose. Navigation feature was created to enable users to navigate the website from one page to another. The storyboard was created to record the content of each page and its description.

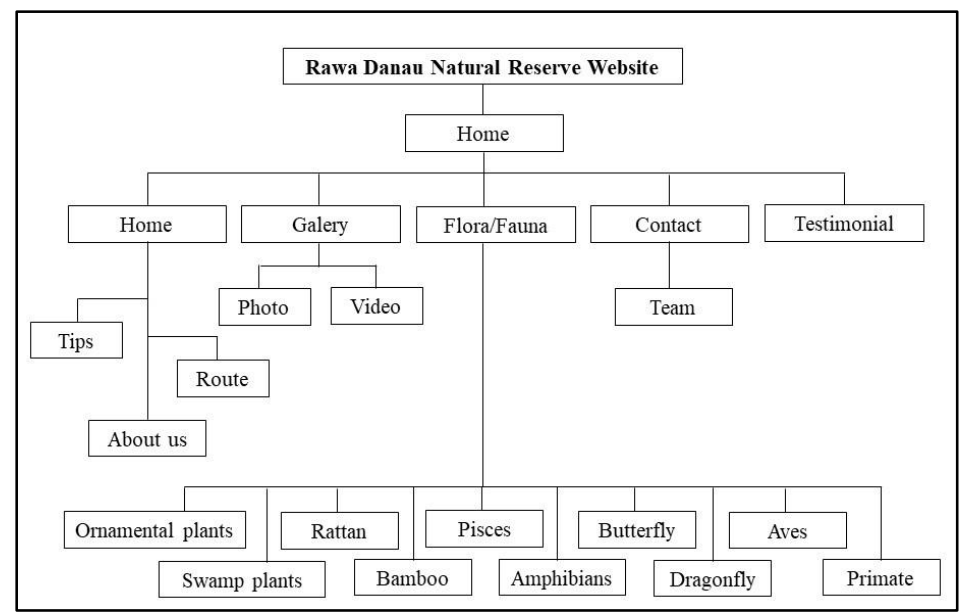

Fig. 1. Navigation for the website on biological conservation education at Rawa Danau Nature Reserve 


\subsection{Collection of content materials}

The content materials for the website were collected during this stage, and they included the main data, including biodiversity data and other supporting data, such as environmental parameters. The data were documented in pictures, videos, and an audio podcast. Secondary data were also collected from the literature and other sources that reported Rawa Danau Nature Reserve biodiversity. These data were usually modified before they were placed on the website as content materials.

\subsection{Assembly}

In the assembly stage, the materials were combined and integrated into the website. CorelDraw X8, Adobe Photoshop, Adobe InDesign, Adobe Premiere, and AVS Video Editor were used.

\subsection{Testing}

The website was tested in two steps. In the alpha test, the creator was the examiner. The alpha test basically verified the website's features and visual navigation. Once the website was well visualized and navigated, it received a beta test, which was the validation of the website by technology experts. The website was also tested using GTMetrix.

The content materials of the websites were validated and assessed by environmentalist / biologist experts and media specialists. The rubrics of the validation consisted of content material, skill that can be achieved after gaining information from this website, and the usability of website (navigation, visual design, compatibility, loading time, accessibility, and interactivity).

\subsection{Distribution}

The last stage was distribution, when the website was ready to be released and published. The website is an open public website, and people with different backgrounds and interests could benefit from the information provided in it. However, the main the target visitors were students.

\section{$3 \quad$ Results and Discussion}

\subsection{The rawa danau nature reserve website}

The biological conservation education website, Pendidikan Konservasi Cagar Alam Rawa Danau, was created for the use in conservation education and to educate people on the importance of nature conservation. The website is based on the existing curricula that focus on five aspects of the purpose of biological conservation education: knowledge, awareness, attitude, skill, and participation [21], and the indicators of 
awareness of the environment include egoistic, humanistic, and biospheric indicators [22]. The content material used for this website was drawn from biodiversity studies conducted at Rawa Danau Nature Reserve over the last several years [23]. This produced information that was up to date, valid, and scientific.

The domain name for the Rawa Danau Nature Reserve website is carawadanau.com. Rawa means swamp in Indonesian, and danau is lake. We used the extension domain.com so that the site could be accessed globally. The administration of Rawa Danau Nature Reserve website is done using a content management system (CMS) to make it easier to develop and update the website content. Another advantage of using a CMS is that it does not require knowledge of a programming language [24]. The CMS used for the website is WordPress. The layout was managed using the design storyboard. The Landing Press Elementor was used as template.

A logo is an important aspect of a website. A logo is memorable and gives an impression of a persona. It is a symbol of recognition, pride, inspiration, and success [25]. We chose the Javanese monkey Lutung Jawa (Trachypithecusauratus mauritius), as it is endemic to the reserve (Fig. 2). The Lutung Jawa is an exotic animal that is protected and listed on CITES (the Convention on International Trade in Endangered Species of Wild Fauna and Flora). It is suitable as the unique icon for the Rawa Danau Nature Reserve website.

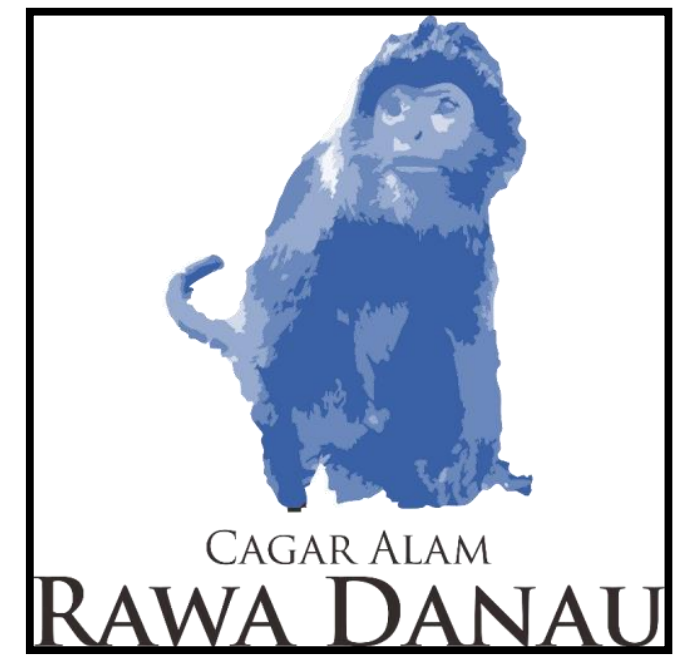

Fig. 2. The Lutung Jawa (Trachypithecusauratus mauritius) in the logo for the Rawa Danau Nature Reserve website

We created six pages on the website and listed them on the menu column, namely, Home, About Us, Gallery, Flora/Fauna, Contacts, and Testimonials. These menus make it easier for users to navigate or browse on this website. In addition, the menus that appear can facilitate visitors to fulfill five areas of conservation education goals [21]. The home page is the first page to appear when the website is opened. This page includes a navigation menu to the gallery, activities (photos and videos), testimony, 
and contact information (Fig. 3). Information on ecotourism, which is linked to biological conservation, is also shown.

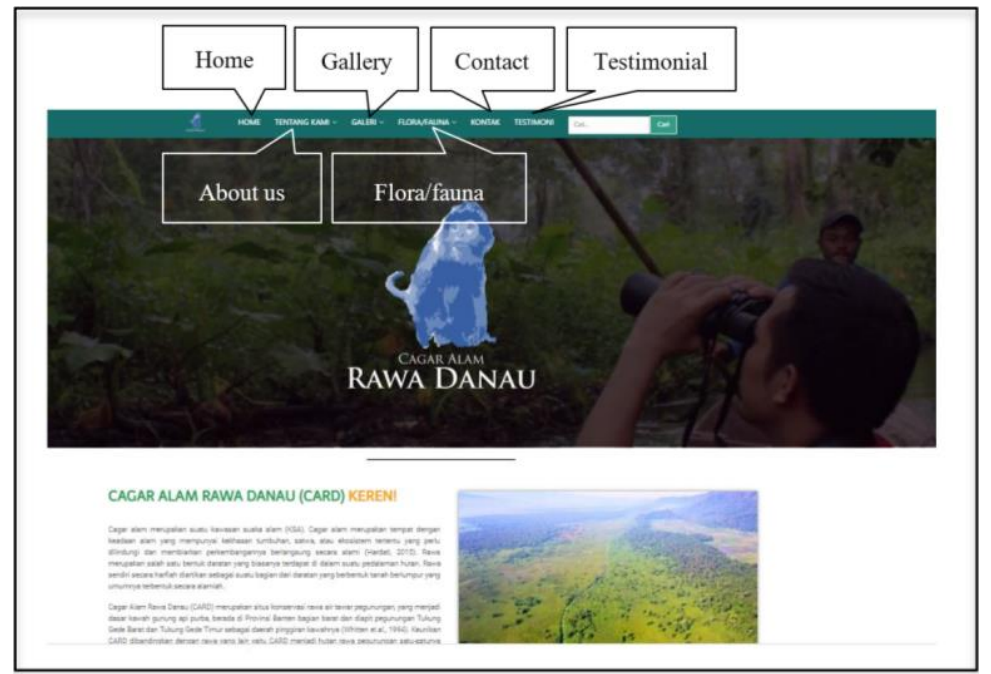

Fig. 3. Home page and menus provided on the Rawa Danau Nature Reserve website

The About Us page covers 4 (four) submenus, i.e., tips, accessibility, the purpose of biology conservation education, and conservation status of flora-fauna identified in Rawa Danau Nature Reserve. In the Tips submenu, preparations for visiting the reserve are provided, such as how to obtain a permit to enter, how to coordinate with the officers there, and how to abide by the necessary ethical guidelines there (Fig. 4a). Due to Rawa Danau's status as a conservation area, certain things must be considered when visiting it, especially for research purposes. It is a mountain freshwater swamp conservation site at the base of an ancient volcanic crater, located in the western part of Banten Province and flanked by the West and East Tukung Gede mountains [26]. Rawa Danau is the only mountain swamp forest on the island of Java. It is upstream of the Cidanau river, which has strategic value and plays an important role in the community as a source of water for industrial and urban areas in Cilegon and Serang as well as being the only reservoir in the area [27]. In the accessibility submenu, provider route and information on how to access Rawa Danau Nature Reserve from nearby cities like Jakarta, Bogor, and Bandung is provided (Fig. 4). For the purpose of biological conservation education, the submenu describes five aspects of conservation, such as knowledge, awareness, attitude, skills, and participation [21]. Next, in the conservation status submenu, conservation status categories based on the International Union for Conservation of Nature and Natural Resources red list are provided (Fig. 4b). 


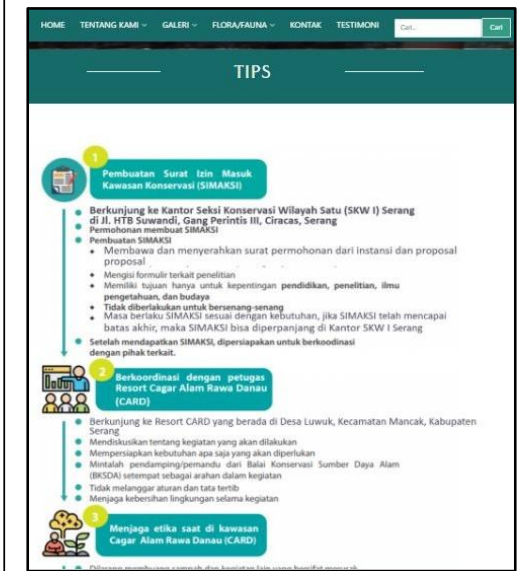

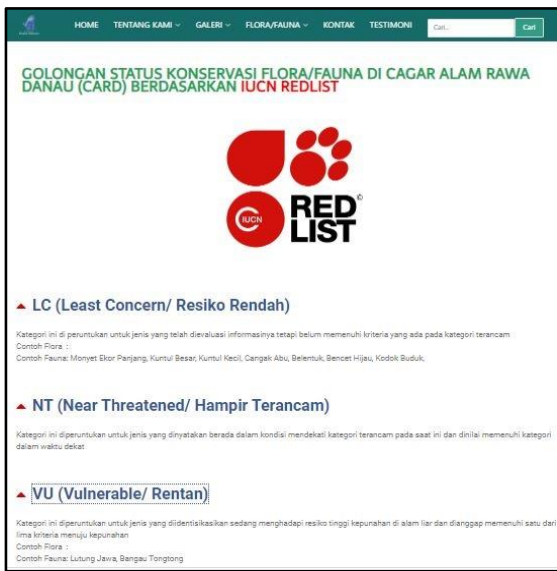

b

Fig. 4. About us page menu, (a) tips submenu and (b) conservation status submenu

The Gallery page menu presents photos and videos of research and social activities conducted in the reserve (Fig. 5). The main purpose of those activities is conservation and related things. The website contains specific photos and icons that are unique to Rawa Danau Nature Reserve. They introduce the public to this beautiful swamp area in Banten. Illustrations, in the form of photos, drawings, and diagrams, have an important role in recognizing certain objects or places due to the value and character that is attached to those objects that can help people to understand their importance [28]. Here, specific photos and figures are provided to introduce Rawa Danau Nature Reserve to public knowledge.

The Flora/Fauna page menu provides information on plant and animal biodiversity in Rawa Danau Nature Reserve with their description and research update. This menu contains eight submenus, each involving research data on plant and animal biodiversity in Rawa Danau, related to primates, birds, amphibians, fish, dragonflies, swamp plants, medicinal plants, and bamboo (Fig. 6). All of the content material, including photos, videos, and other documentation, is the result of fundamental research based in Rawa Danau Nature Reserve on, in particular, the animals, primates [29], birds [30], amphibians [31], fish [32], and dragonflies [33], as well as plants, such as swamp plants [34], medicinal plants [35], and bamboo [17].

In the Contact menu, detailed information on the address of the Rawa Danau Nature Reserve is given, along with information on how to correspond with its representatives. The visitor website could also ask questions about Rawa Danau Nature Reserve to our expert in biological conservation education and other researchers who are doing research on biodiversity at the Rawa Danau Nature Reserve. The final contains the testimony page, which contains statements from students, researcher, and 
environmental activists on Rawa Danau Nature Reserve. Website visitors also provide testimony on how useful the information provided in the website.

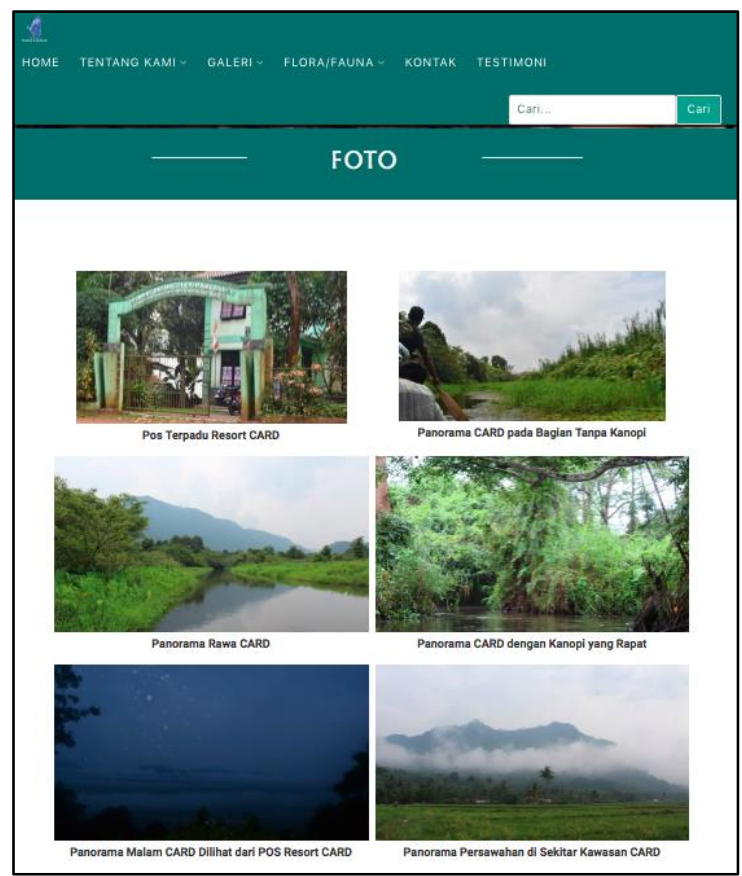

Fig. 5. Gallery" page menu, (a) tips sub menu and (b) conservation status sub menu

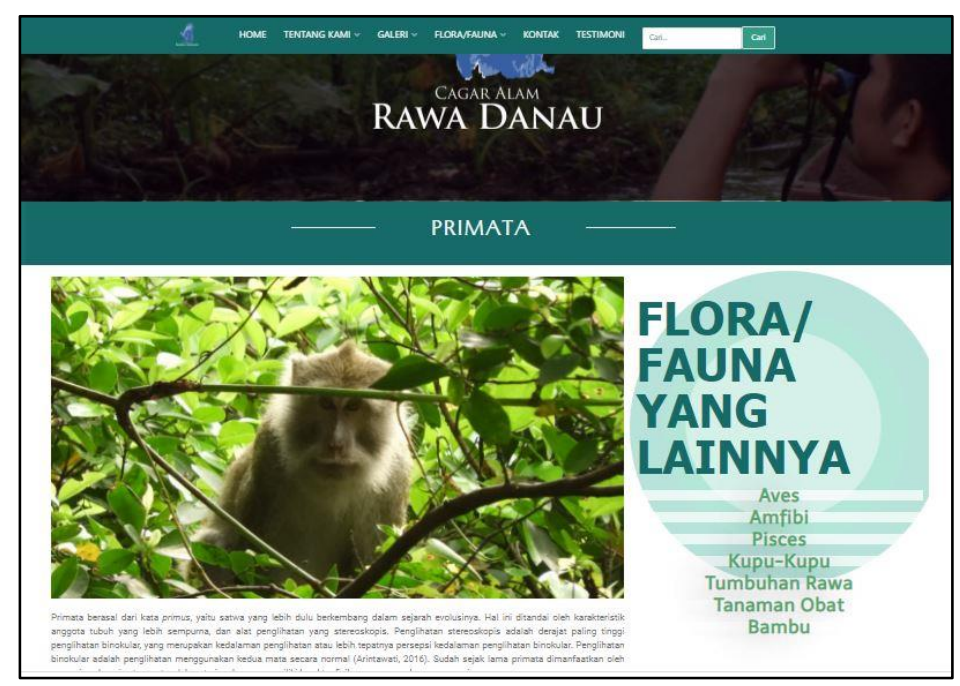

Fig. 6. Primate submenu in the Flora / Fauna menu 


\subsection{Website validation test}

We performed an alpha and beta test of the website. All of the navigation features of the website showed very good performance and fast response to random access. The overall GT indicated good performance for the website (Fig. 7).

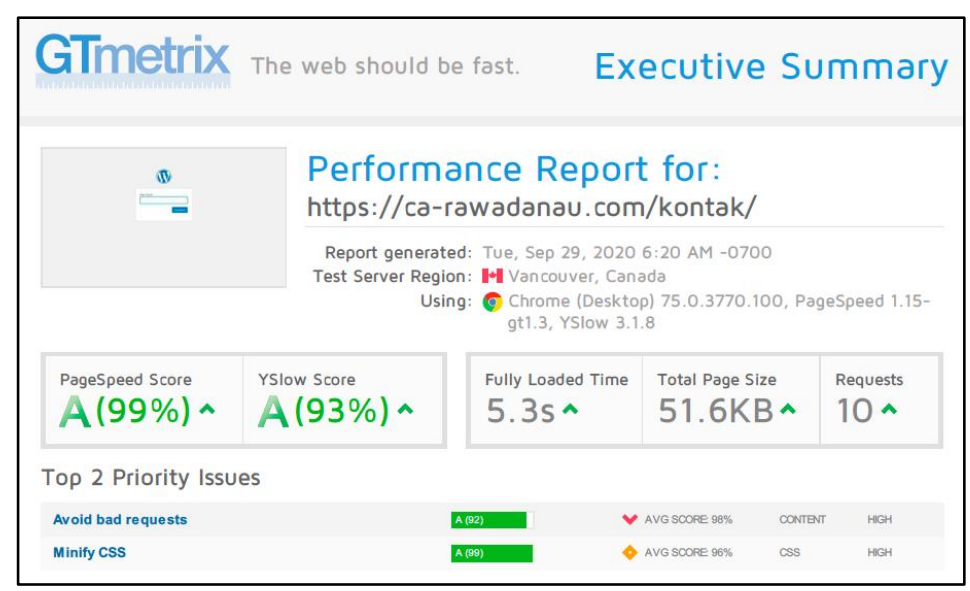

Fig. 7. Results of the GT-Metrix test

To validate the developed product as learning material, expert assessment was sought, in terms of both the learning media and the material content. The average value of the site for learning media aspect was $79.97 \%$, including the usability, navigation, visual design, content, compatibility, time of loading, accessibility, and interactivity (Fig. 8). The highest result was visual design of the website. This means that the Rawa Danau Nature Reserve website can be used as a learning source for biological conservation education. The basic components to develop a website as a learning source are needed to cover the eight criteria noted above [36]. The validation result of Rawa Danau Nature Reserve website in the content material has an average value $79.38 \%$, including content coverage, accuracy, current issue, knowledge of biological conservation, skills, and environmental awareness (Fig. 9). The content coverage had the highest feasibility. This is as was expected, as the content material of the website was mainly based on biodiversity data produced from our previous research. Thus, it covers a link and relatedness to biology conservation education. 


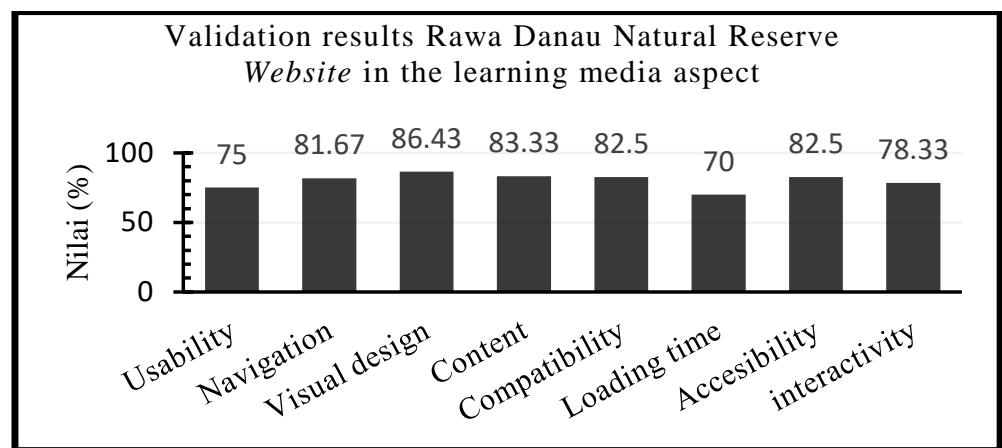

Fig. 8. Expert validation results for the Rawa Danau Nature Reserve website in terms of learning media

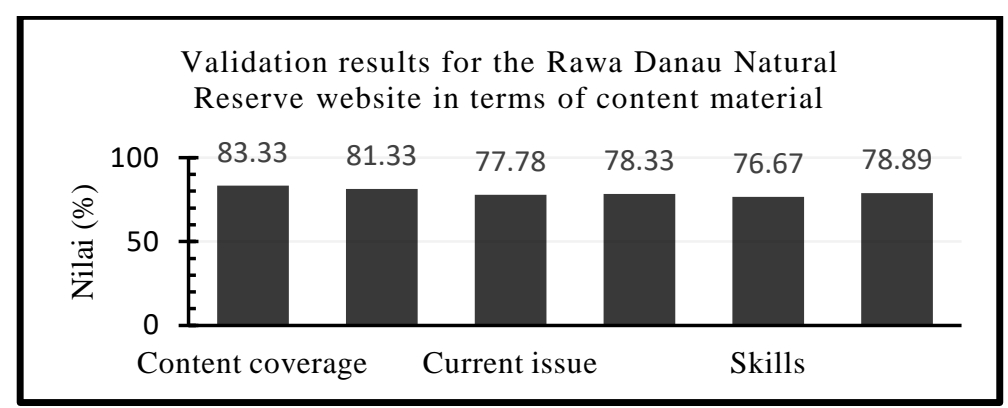

Fig. 9. Expert validation results for the Rawa Danau Nature Reserve website in terms of content materials

The expert validation result showed that the product developed in this research, the Rawa Danau Nature Reserve website, has possibilities for use as an online learning source to support conservation education. The implementation of website-based learning can increase the student cognition [37] and the enthusiasm of both teacher and students as well [38]. In addition, web-based learning is an alternative to traditional pedagogical approaches and learning techniques that can be appropriate to students' psychological needs and can allow collaboration, stimulate creativity, and enable analytical thinking for solving problems [39].

\section{Conclusion}

We developed a website-based learning source for biological conservation education. The Rawa Danau Nature Reserve website, which can be accessed at https://carawadanau.com, was found to be feasible for use in biological conservation education. The site was found to be useful for increasing the awareness of the environment and nature conservation. Finally, the website could benefit a broad range of people as their knowledge, awareness, attitudes, skills, and participation in nature conservation improve. 


\section{$5 \quad$ Acknowledgement}

The author would like to thank Rawa Danau Natural Reserve exploration team in Biology Department, Faculty of Teacher Training and Education, University of Sultan Ageng Tirtayasa (UNTIRTA). Also, to Institute for Research and Community Service (LPPM) UNTIRTA which have supported and funded this research.

\section{References}

[1] Mailizar, Almanthari, A., Maulina, S., Bruce, S.B. (2000). Secondary School Mathematics Teachers' Views on E-learning Implementation Barriers During the COVID-19 Pandemic: The Case of Indonesia. EURASIA Journal of Mathematics, Science and Technology Education. 16(7): 1-9. https://doi.org/10.29333/ejmste/8240

[2] KEMENDIKBUD (Indonesia mnisitry of Education). Kebijakan Merdeka Belajar. https://www.kemdikbud.go.id. December 11th, 2019 [Accessed October 1st, 2020].

[3] Bhaumik, R., Anita, P. (2020). Readiness of Senior Secondary School Learners to Online Learning Transition Amid COVID-19 Lockdown. Asian Journal of Distance Education. 15(1): 244-256. doi:10.5281/zenodo.3891822

[4] Crawford, J., Butler-Henderson, K., Jürgen, R., Malkawi, B., Glowatz, M., Burton, R., Magni, P.A., Lam, S. (2020). COVID-19: 20 Countries' Higher Education Intra-Period Digital Pedagogy Responses. Journal of Applied Learning \& Teaching. 3(1): 9-28. https://doi.org/10.37074/jalt.2020.3.1.7

[5] Ferdig, R.E., Baumgartner, E., Hartshorne, R., Kaplan-Rakowski, R., Mauza, C. (2020). Teaching, Technology, and Teacher Education During the COVID-19 Pandemic: Stories from the Field. https://www.learntechlib.org/p/216903/ [accessed December 2nd, 2020]

[6] Abidah, H. N. Hidayaatullah, R.M. Simamora, D. Fehabutan, Mutakinati, L. (2020). The Impact of Covid-19 to Indonesian Education and Its Relation to the Philosophy of "Merdeka Belajar". Studies in Philosophy of Science and Education (SiPoSE) 1(1): 38-48. https://doi.org/10.46627/sipose.v1i1.9

[7] Ali, R.A., \& Arshad, M.R.M.A. (2017). Investigating the Perception of Students Regarding MLearning Concept in Egyptian Schools. International Journal of Interactive Mobile Technologies, 11(6): 112-122. https://doi.org/10.3991/ijim.v11i6.7361

[8] Al-Hunaiyyan, A., Sharhan, S.A., \& Alhajri, R. (2017). A New Mobile Learning Model in the Context of Smart Classroom Environment: A Holistic Approach. International Journal of Interactive Mobile Technologies, 11(3): 39-56. https://doi.org/10.3991/ijim.v11i3.6186

[9] Hudha, M.N., Chaeruman, U.A., Hakim, A.R., Sundaygara, C., Kumala, F.N., Batlolona, J.R., Fajaruddin, S., Andi, T., Yusro, A.C., Rangka, I.B., Nandiyanto, A.B.D., Abdullah, A.G. (2019). Simple Electrical Motor for Elementary School Future Teachers Through Scientific Work E-Rubric. Journal of Physics.1318:1-4. https://doi.org/10.1088/1742$\underline{6596 / 1318 / 1 / 012004}$

[10] Ismail, I., Rozhan, M., Thenmolli, G. (2010). Motivation, Psychology and Language Effect on Mobile Learning in Universiti Sains Malaysia. International Journal of Interactive Mobile Technologies. 4 (4): 31-36. https://doi.org/10.3991/ijim.v4i4.1408

[11] El-Soud, S.A., Hosam, F. E., Yahia, A. (2010). Wireless "Questions-Bank" System to enhance M-learning in School Education. International Journal of Interactive Mobile Technologies. 4 (1): 4-8. https://doi.org/10.3991/ijim.v4i1.1129

[12] Tambunan, H. (2013). Pengembangan Pembelajaran Berbasis Website dalam Mata kuliah Pengaturan Mesin Listrik. Jurnal Cakrawala Pendidikan. 32(1): 64-76. https://doi.org/10. 21831/cp.v5i1.1260 
[13] Mulhem, A. (2020). Exploring the Key Factors in the Use of an E-Learning System Among Students at King Faisal University, Saudi Arabia. International Journal of Interactive Mobile Technologies, 14(3): 19-37. https://doi.org/10.3991/ijim.v14i03.11576

[14] Al-Khalifa, H.S. (2011). On the Development of a Web-Based M Learning System for Dual Screen Handheld Game Consoles. International Journal of Interactive Mobile Technologies. 5 (2): 4-8. https://doi.org/10.3991/ijim.v5i2.1530

[15] Chang, C., C. Tzung-Shi, H. Wei-Hsiang. (2011). The Study on Integrating WebQuest with Mobile Learning for Environmental Education. Elsevier. 5: 1228-1239. https://doi.org/10.1016/j.compedu.2010.12.005

[16] Peterson, M. (1998). The Virtual Learning Environment: The Design of a Website for Language Learning. Computer Assisted Language Learning. 11(4): 349-361. https://doi.org/10.1076/call.11.4.349.5669

[17] Leksono, S.M., Marianingsih, P., Rahmah, S.S.A. (2019). Buku Panduan Lapangan Pendidikan Konservasi: Keanekaragaman Bambu di Cagar Alam Rawa Danau. Media Edukasi Indonesia. Jakarta.

[18] Wihardjo, S. D., Hartati, S., Nurani, Y., Sujarwanta, A. (2017). The Effects of Green Schooling Knowledge Level and Intensity of Parental Guidance on the Environmental Awareness of The Early Age Student. Educational Research and Reviews. 12(5): 251-257. https://doi.org/10.5897/err2015.2608

[19] Handoyo, E., Tijan, Model Pendidikan Karakter Berbasis Konservasi:Pengalaman Universitas Negeri Semarang. (2010). Universitas Negeri Semarang Press bekerjasama Penerbit Widya Karya. Semarang. https://doi.org/10.17501/icedu.2018.4101

[20] Luther, A.C. (1994). Authoring Interactive Multimedia. AP Profesional. Buston

[21] Setyowati, D.L., Sunarko, Rudatin, Sedyawati, S.M.R. (2014). Pendidikan Lingkungan Hidup. Universitas Negeri Semarang. Semarang.

[22] Hidayat, A. (2016). Studi Tentang Pengaruh Kepedulian Lingkungan, Prilaku Konservasi, dan Perilaku Hijau Terhadap Sikap Skeptis Pada Iklan Hijau. Universitas Negeri Yogyakarta. Yogyakarta. https://doi.org/10.31227/osf.io/3u2tq

[23] Leksono, S.M., Firdaus, N. (2017). Pemanfaatan Keanekaragaman Amfibi (Ordo Anura) di Kawasan Cagar Alam Rawa Danau Serang Banten Sebagai Material Edu-Ekowisata, Journal Proceeding Biology Education Conference. 14(1).

[24] Junaidi, A. Modul Pembelajaran Wordpress dan Joomla! Modula. Bandung.

[25] Febriansyah. (2013). Pengaruh Perubahan Logo (Rebranding) Terhadap Citra Merek Pada PT Telkom tbk Di Bandar Lampung. Jurnal JMA. 18(2): 1-24. https://doi.org/10.32493/ frkm.v1i4.2563

[26] Whitten, T., Soriaatmadja, R.E., Afiff, S.A. (2006). Ekologi Jawa dan Bali Jilid 2. Prenhalindo. Jakarta.

[27] Dinas Lingkungan Hidup dan Kehutanan Provinsi Banten (environment and forestry agency Banten province). (2018). Ringkasan Eksekutif (executive summary) Cagar Alam Rawa Danau. DLHK. Banten.

[28] Kusrianto, A. (2007). Pengantar Desain Komunikasi Visual. ANDI. Yogyakarta.

[29] Leksono, S.M., Marianingsih, P., Taufikullah, M. (2020). Buku Panduan Lapangan Primata di Cagar Alam Rawa Danau. Universitas Sultan Ageng Tirtayasa. Serang.

[30] Leksono, S.M., Marianingsih, P., Dewi, N.A. (2020). Field Guide Book: Pesona Avifauna Cagar Alam Rawa Danau. Universitas Sultan Ageng Tirtayasa. Serang.

[31] Leksono, S.M., Marianingsih, P., Yulyawati A. (2020), Buku Panduan Lapangan Amfibi Cagar Alam Rawa Danau. Universitas Sultan Ageng Tirtayasa. Serang.

[32] Leksono, S.M., Marianingsih, P., Cahyadi, Y. (2020). Buku Panduan Lapangan Ikan: Mengenal dan Menjaga Kelestarian Cagar Alam Rawa Danau dan Spesies Ikan yang Hidup di dalamnya. Universitas Sultan Ageng Tirtayasa. Serang. https://doi.org/10.24114 /sejpgsd.v7i1.6827 
[33] Leksono, S.M., Marianingsih, P., Rahmawati, R.N. (2019). Buku Panduan Lapangan Berbasis Pendidikan Konservasi: Keanekaragaman Capung di Cagar Alam Rawa Danau, Serang, Banten. Universitas Sultan Ageng Tirtayasa. Serang. https://doi.org/10.30596/ ekonomikawan.v19i2.3820

[34] Leksono, S.M., Marianingsih, P., Adawiyah, D.R. (2019). Buku Panduan Lapangan: JenisJenis Tumbuhan Rawa di Cagar Alam Rawa Danau. Universitas Sultan Ageng Tirtayasa. Serang.

[35] Leksono, S.M., Marianingsih, P., Rahmawati, D. (2020). Buku Panduan Lapangan: Mengenal Tanaman Obat di Cagar Alam Rawa Danau. Universitas Sultan Ageng Tirtayasa. Serang.

[36] Suryanto, A.H. (2007). Step by Step: Web Design Theory and Practices. ANDI. Yogyakarta.

[37] Bhaskar, N.U., Govindarajulu, P. (2010). Advanced and Effective Learning in Context Aware and Adaptive Mobile Learning Scenarios. International Journal of Interactive Mobile Technologies. 4 (1): 9-13. https://doi.org/10.3991/ijim.v4i1.1086

[38] Åberg, E.S., Ylva S., Ingrid, E., Helen, K. (2016). Designing a Website to Support Students' Academic Writing Process. The Turkish Online Journal of Educational Technology (TOJET). 15(1): 33-42

[39] Derisma. (2020). The Usability Analysis Online Learning Site for Supporting Computer programming Course Using System Usability Scale (SUS) in a University. International Journal of Interactive Mobile Technologies, 14(9): 182-195. https://doi.org/10.3991/ ijim.v14i09.13123

\section{Authors}

Dr. Suroso Mukti Leksono is a senior lecturer at the Department of Science Education, Faculty of Education and Teacher Training, Universitas Sultan Ageng Tirtayasa UNTIRTA, J1. Ciwaru No.25 Kota Serang, Banten Indonesia. Email: $\underline{\text { su- }}$ mule56@untirta.ac.id

Pipit Marianingsih, M.Si. is a lecturer at the Department of Biology Education, Faculty of Education and Teacher Training, Universitas Sultan Ageng Tirtayasa UNTIRTA, Jl. Ciwaru No.25 Kota Serang, Banten Indonesia.

Eprian Nur Ilman, S.Pd. is a research assistant at the Department of Biology Education, Faculty of Education and Teacher Training, Universitas Sultan Ageng Tirtayasa UNTIRTA, J1. Ciwaru No.25 Kota Serang, Banten Indonesia.

Dr. Nani Maryani is a lecturer at the Department of Biology Education, Faculty of Education and Teacher Training, Universitas Sultan Ageng Tirtayasa UNTIRTA, Banten Indonesia. She is also a researcher at the Indonesia Center of Excellence on Food Security (ICEFORY), UNTIRTA, Banten Indonesia.

Article submitted 2021-01-28. Resubmitted 2021-02-26. Final acceptance 2021-02-27. Final version published as submitted by the authors. 